\title{
Protein S100-B
}

National Cancer Institute

\section{Source}

National Cancer Institute. Protein S100-B. NCI Thesaurus. Code C98129.

Protein S100-B (92 aa, $\sim 11 \mathrm{kDa}$ ) is encoded by the human S100B gene. This protein is involved in metal-cation binding and neuronal signaling and development. 